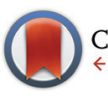

CrossMark \& click for updates

Cite this: Food Funct., 2016, 7, 2320

\title{
Potential antimicrobial and antiproliferative activities of autochthonous starter cultures and protease EPg222 in dry-fermented sausages
}

\author{
Margarita Fernández, ${ }^{a}$ Santiago Ruiz-Moyano, ${ }^{a, b}$ María José Benito, ${ }^{a, b}$ \\ Alberto Martín, ${ }^{a, b}$ Alejandro Hernández ${ }^{a, b}$ and María de Guía Córdoba ${ }^{a, b}$
}

\begin{abstract}
This work studied the presence of nitrogen compounds with bioactive properties in Iberian pork sausages that were manufactured using different autochthonous starter cultures (Pediococcus acidilactici MS200 and Staphylococcus vitulus RS34) and protease EPg222. Nitrogen compounds were extracted and evaluated for their antimicrobial effect against spoilage and pathogenic bacteria, such as Bacillus cereus, Escherichia coli, Salmonella choleraesuis, Staphylococcus aureus and Listeria monocytogenes, and antiproliferative activity on the HT-29 colon adenocarcinoma cell line. Dry-fermented sausages elaborated with starter cultures P200S34 and protease EPg222 generate extracts that cause inhibition of the growth of pathogens reaching $25 \%$ inhibition of Bacillus cereus, making this a promising tool for biocontrol in the meat industry. On the other hand, the inoculation of well-adapted starter cultures with high proteolytic activity also increased the antiproliferative activity of these extracts, around $45 \%$ inhibition at $72 \mathrm{~h}$, mainly due to an increase in free amino acids, such as Lys and Pro, but also small peptides.
\end{abstract}

Received 23rd February 2016 Accepted 15th April 2016

DOI: $10.1039 / \mathrm{c} 6 f \circ 00236 f$ www.rsc.org/foodfunction microorganisms that have been used as starter cultures in the manufacture of cured meat products are lactic acid bacteria (LAB) and staphylococci. ${ }^{7,8} \mathrm{LAB}$ are responsible for the drop in $\mathrm{pH}$ during ripening as a consequence of organic acid production, and can also produce small peptides called bacteriocins, which contribute to the safety of the final product. ${ }^{9}$ However, the effectiveness of bacteriocins in the sausage can be influenced by a wide range of factors, such as their limited spectrum of action, physical conditions, low production under the manufacturing conditions, genetic instability, low diffusion and solubility throughout the product, inactivation by meat proteases and resistance of the target strain, as well as interference by meat components, in particular, adsorption to fat and meat particles or inhibition by salt and curing agents. ${ }^{10,11}$ Consequently, research into new natural antimicrobial substances to control foodborne pathogens in dry-cured sausages remains an important objective for this industry.

Many authors have demonstrated the capacity of bioactive peptides derived from food to inhibit foodborne pathogens. ${ }^{12-15}$ These peptides can be produced from precursor proteins through the proteolytic actions of microorganisms, and starter and non-starter cultures, or by in vitro enzymatic hydrolysis with enzymes from microbial, animal or plant origins, chemical synthesis or food processing. ${ }^{16}$ LAB and staphylococci have extracellular and intracellular proteinases and peptidases suitable for the production of bioactive peptides. ${ }^{17,18}$ Proteolytic starter cultures have been used to generate antimicrobial peptides from different food matrices. ${ }^{19-21}$

\footnotetext{
${ }^{a}$ Nutrición y Bromatología, Escuela de Ingenierías Agrarias, Universidad de Extremadura, Avd. Adolfo Suárez s/n, 06007 Badajoz, Spain.

E-mail: mjbenito@unex.es; http://eia.unex.es; Fax: +34 924 286201; Tel: +34924286200

${ }^{b}$ Instituto Universitario de Recursos Agroalimentarios (INURA), Universidad de Extremadura, Avd. de la Investigación s/n, 06006 Badajoz, Spain
} 
Peptides generated during the ripening process can also have other biological properties that may exert beneficial physiological effects, such as antiproliferative activity toward to cancer cells. In fact, studies with tumour and normal human cell lines of different compounds are nowadays very important. Cancer is one of the largest single causes of death in both men and women. ${ }^{22}$ Frequently, resistance to anticancer drugs has been observed. ${ }^{23}$ Therefore, the research and development of more effective and less toxic drugs by the pharmaceutical industry has become necessary, prompting a growing interest in the identification and characterisation of natural antitumor agents. The elimination of cancer in the early stages is an integral part of chemoprevention, and measuring the cytotoxic properties of a given compound against cancer cells provides useful insight into its chemoprotective potential. However, no reference has been made in previous reports of any antiproliferative/cytotoxic effect of fermented pork meat product-derived peptides on cancer cells.

To date, antihypertensive and antioxidant properties in peptides from meat and fermented meat products have been widely investigated; however, other beneficial effects such as antimicrobial and antiproliferative potential have been scarcely addressed. ${ }^{13,24,25}$ In this study, we applied starter cultures and protease EPg222, with a demonstrated proteolytic activity, ${ }^{26-28}$ generate bioactive nitrogen compounds during ripening of dry cured sausages ${ }^{29,30}$ The aim of this work was to investigate about the presence of nitrogen compounds with antimicrobial and antiproliferative properties in dry-cured Iberian pork sausages manufactured with different autochthonous starter cultures and protease EPg222.

\section{Materials and methods}

\subsection{Biological material}

For this work, the dry-fermented sausage "salchichón" manufactured as described by Casquete et al. ${ }^{28}$ In the manufacture of dry-fermented sausages, two autochthonous microorganisms, Pediococcus acidilactici MS200 and Staphylococcus vitulus RS34, as well as the protease EPg222 were used. ${ }^{27,31-33}$ In total, four different batches were prepared: a control batch without the addition of a starter culture (Control); a second batch with both the $P$. acidilactici strain and S. vitulus RS34 (P200S34); a batch elaborated with the protease EPg222 alone (EPg222); and finally a batch with EPg222 in combination with the starter culture containing P. acidilactici MS200 and S. vitulus RS34 (EPg222 + P200S34). Samples were taken from three different sausages from each batch at 60 days and at the end of the ripening after 90 days and the analysis were conducted in duplicate.

\subsection{Physicochemical and microbial analysis}

The moisture content was measured by dehydration at $100{ }^{\circ} \mathrm{C}$ by the ISO recommended methods. ${ }^{34}$ Water activity (Aw) was calculated using a water activity meter model FA-St/1 (GBX FAST lab, France). The pH was determined using an electrode
Crison model 2002 pH meter (Crison Instruments, Barcelona, Spain). We also investigate the presence of strains inoculated at high levels in the different batches. The Staphylococcus count was determined in mannitol salt agar (MSA) at $30^{\circ} \mathrm{C}$ for $48 \mathrm{~h}$, and lactic acid bacteria were grown in Man-Rogosa-Sharpe agar (MRS) (Oxoid) with the $\mathrm{pH}$ adjusted to 5.6 at $37^{\circ} \mathrm{C}$ under anaerobic conditions for $48 \mathrm{~h}$. Ten colonies from the plates with the highest dilutions were isolated, and 16S rRNA gene sequence analysis was performed as described by Benito et al. ${ }^{32,35}$ Sequences were compared with the EMBL and GenBank databases using the BLAST algorithm and the identities of the isolates were determined on the basis of the highest score.

\subsection{Nitrogen compound extraction}

The nitrogen compounds were extracted according to De Ketelaere et $a .^{36}$ and Bauchart et $a .^{37}$ Each sample (15 g) was homogenised in $0.6 \mathrm{~N}$ perchloric acid using an Omni Mixer Homogeniser. The homogenate was centrifuged for $15 \mathrm{~min}$ at $4000 \mathrm{rpm}$. The soluble fraction located between the upper layer and the precipitate was filtered through Whatman no. 54 filter paper. The $\mathrm{pH}$ was neutralised to $\mathrm{pH} 6$ with $30 \% \mathrm{KOH}$. To eliminate the potassium perchlorate formed during neutralisation, extracts were filtered again. Finally, extracts were ultrafiltrated through a hydrophilic 10- and 5-kDa cut-off membrane (Pellicon XL, Millipore Corporation, Billerica, MA, USA). The protein content of the 5 -kDa permeate extracts was determined by the colorimetric method based on a bicinchoninic acid (BCA) assay kit (Pierce, Rockford, IL, USA), using bovine serum albumin as the standard protein. The different extracts were lyophilised and kept frozen at $-80{ }^{\circ} \mathrm{C}$ until antibacterial and antiproliferative activity testing.

\subsection{In vitro pepsin/pancreatin-simulated gastrointestinal (GI) digestion}

Simulated GI digestion using in vitro pepsin/pancreatin hydrolysis was carried out according to Cinq-Mars et al. ${ }^{38}$ and You et al. ${ }^{39}$ with slight modifications. The $\mathrm{pH}$ of the nitrogen compound extracts was adjusted to $\mathrm{pH} 2.0$ with $1 \mathrm{M} \mathrm{HCl}$ and incubated at $37{ }^{\circ} \mathrm{C}$ with pepsin $(4 \%$ weight as received/weight of protein in the powder ( $\sim 85 \%$ protein)) for $90 \mathrm{~min}$. Before pancreatic digestion, the $\mathrm{pH}$ was adjusted to $\mathrm{pH} 7.5$ with $1 \mathrm{M}$ $\mathrm{NaOH}$. Pancreatin was added (4\% weight as received/weight of protein in the powder $(\sim 85 \%$ protein $))$, and the mixture was incubated at $37{ }^{\circ} \mathrm{C}$ for $2 \mathrm{~h}$. To terminate the digestion, the test tubes were kept in boiling water for $10 \mathrm{~min}$. Finally, the protein content of the 5 -kDa permeate extracts was determined by the BCA method using bovine serum albumin as the standard protein and the different extracts were lyophilised and kept frozen at $-80^{\circ} \mathrm{C}$ until antibacterial and antiproliferative assays.

\subsection{Antibacterial activity assay}

Inhibitory effects of nitrogen compound extracts before and after GI digestion on selected potentially harmful microorganisms were studied by following the ability of the target microbes to grow in a medium containing sterilised extracts, as described Ruiz-Moyano et $a{ }^{40}{ }^{40}$ Selected pathogen bacteria 
were obtained from the Spanish Type Culture Collection. The strains were grown at least twice prior to the experiment in Brain-Heart Infusion broth (BHI; Scharlab, Barcelona, Spain) for $18 \mathrm{~h}$ at $37^{\circ} \mathrm{C}$ (E. coli CECT4267, S. choleraesuis CECT4395, S. aureus CECT976, L. monocytogenes CECT911, B. cereus CECT131). The nitrogen compound extracts were reconstituted in Milli-Q water at $600 \mu \mathrm{g} \mathrm{mL}^{-1}$ and filter-sterilised. The test

$\%$ Antiproliferative activity $=[($ Absorbance negative control -

was performed in 100-well flat-bottomed honeycomb plates; $247 \mu \mathrm{L}$ of BHI broth was inoculated with $3 \mu \mathrm{L}$ from a suspension of tested microorganisms at $10^{8} \mathrm{cfu} \mathrm{mL}^{-1}$ and $50 \mu \mathrm{L}$ of test fractions (final concentration: $100 \mu \mathrm{g} \mathrm{mL} \mathrm{m}^{-1}$ ). BHI broth inoculated with test microorganisms and $50 \mu \mathrm{L}$ of Milli-Q water was used as a control. The ability of each strain to grow in supplemented broth was evaluated by following microbial growth at $37{ }^{\circ} \mathrm{C}$ for $24 \mathrm{~h}$ with an automated turbidometer (Bioscreen C Analysis System; Labsystems, Finland). The optical density was measured with a wide-band filter (OD 420-580 nm). The absorbance was measured at 15 min intervals during the incubation period preceded by 10 seconds shaking at medium speed. The inhibitory effect of the nitrogen compound extracts on the foodborne pathogens was determined by comparing the turbidity readings of each strain with those obtained in the absence of nitrogen compound extracts. The percentage inhibition was calculated with the following formula:

$$
\% \text { inhibition }=\left(\mathrm{Abs}_{\text {control }}-\mathrm{Abs}_{\text {assay }} / \mathrm{Abs}_{\text {control }}\right) \times 100
$$

where $\mathrm{Abs}_{\text {control }}$ is the optical density of the growth of the test strain in the absence of nitrogen compound extracts and $\mathrm{Abs}_{\text {strain }}$ is the optical density of the growth of the test strain in the presence of nitrogen compound extracts.

\subsection{Determination of antiproliferative activity}

The antiproliferative test was carried out using the HT-29 ATCC HTB-38 human colorectal adenocarcinoma cell line. The cells were routinely grown in McCoy's 5A medium containing $10 \%$ FBS and incubated at $37^{\circ} \mathrm{C}$ in a humidified atmosphere containing $5 \% \mathrm{CO}_{2}$. Cells were seeded at $5 \times 10^{3}$ cells per well in 96-well plates, and incubated in $100 \mu \mathrm{L}$ of complete culture medium for $24 \mathrm{~h}$ prior to the addition of the samples. At this time, HT-29 cells were incubated with culture media containing nitrogen compounds at a final concentration of $1 \mathrm{mg} \mathrm{mL} \mathrm{m}^{-1}$ for all extracts prior to and after digestion, as described above. Phosphate-buffered saline $\mathrm{pH} 7.4$ (PBS) was used as a negative control, whereas quercetin (Sigma, St. Louis, MO) at a final concentration of $200 \mu \mathrm{M}$ was used as the positive control. Media of each treatment and control were replaced daily and the proliferation of the cells was assessment using the colorimetric MTT (3-(4,5-dimethylthiazol-2-yl)-2,5-diphenyl tetrazole; Sigma) assay according to Olsen et $a .^{41}$ with slight modifications, at 24, 48 and $72 \mathrm{~h}$. To determine the living cells, the medium was removed and $200 \mu \mathrm{L}$ of non-supplemented medium plus $50 \mu \mathrm{L}$ of MTT solution at $5 \mathrm{mg} \mathrm{mL}^{-1}$ was added to each well followed by incubation at $37^{\circ} \mathrm{C}$ for $4 \mathrm{~h}$. The result- ing blue MTT formazan precipitate was dissolved in $200 \mu \mathrm{L}$ of dimethyl sulfoxide (DMSO; Sigma) and the absorbance measured at $570 \mathrm{~nm}$ using a Fluostar Optima microplate reader (BMG LABTECH, Offenburg, Germany). The antiproliferative effect was calculated as the percentage of growth inhibition with respect to the negative control cells, according to the following equation:

\section{(Absorbance negative control) $] \times 100$.}

\subsection{HLPC-ESI-MS analysis of the extracts}

The nitrogen compounds presents in the extracts were analysed by HLPC-ESI-MS on an Agilent series 1100 apparatus (Agilent Technologies, Palo Alto, USA). The chromatographic conditions applied were as in Gómez-Ruiz et al. ${ }^{42}$ A Supelcosil LC-18 column (SUPELCO, Bellafonte, USA) was utilised with mobile phase (A) being a mixture of water and trifluoroacetic acid (1000: 0.37, v/v) and (B) being acetonitrile and trifluoroacetic acid $(1000: 0.27, \mathrm{v} / \mathrm{v})$ in a gradient of solvent $\mathrm{B}$ in $\mathrm{A}$ increasing from $0 \%$ to $45 \%$ in $60 \mathrm{~min}$, and from $45 \%$ to $70 \%$

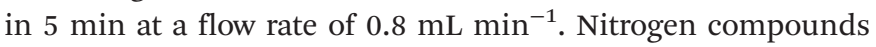
were distinguished on an Agilent series 6100 Series Single Quad LC/MS (Agilent Technologies) equipped with a multimode source in electrospray ionization mode by their mass spectrum and retention time. The MS conditions were positive ionization mode; mass range for full scan was $\mathrm{m} / \mathrm{z} 100-1500$; capillary voltage: $2 \mathrm{kV}$; fragmentor voltage $80 \mathrm{~V}$; dry gas: $\mathrm{N}_{2}$ $10 \mathrm{~min}^{-1}, 250{ }^{\circ} \mathrm{C}$ and nebulizer pressure: 50 psi. Standards of amino acids (alanine, arginine, aspartic acid, cystine, glutamic acid, glycine, histidine, isoleucine, leucine, lysine, methionine, phenylalanine, proline, serine, threonine, tyrosine, valine and taurine), biogenic amines (cadaverine, histamine, putrescine, tryptamine, tyramine, 2-phenylethylamine, spermine and spermidine) and carnitine (Sigma-Aldrich Química S.A., Madrid, Spain) were used. The other nitrogen compounds detected were tentatively identified by their mass spectra.

\subsection{Statistical analysis}

Statistical analysis of the data was carried out using one-way analysis of variance (ANOVA), and the means were compared by Tukey's honest significant difference (HSD) test, $(p \leq 0.05)$ using SPSS for Windows, 22.0. (SPSS Inc. Chicago, IL, USA). The functional activities were studied by variance mixed ANOVA. The relationships between the nitrogen compounds and the functional activities found in the extracts at the end of the processing of the fermented meat sausages were estimated by principal component analysis (PCA).

\section{Results and discussion}

Physicochemical factors, such us moisture content, water activity (aw) and $\mathrm{pH}$ values, did not differ significantly between the control, EPg222 and starter culture batches. pH decreased from about 6.3 to 4.9 during ripening, and was 5.7 at the end of the process in all batches. 
The moisture content decreased from initial values of $65 \%$ to $30 \%$ at the end of ripening. Water activity ranged from values of 0.95 to 0.82 at the end of ripening in all batches. These results are similar to those reported by Benito et al. ${ }^{33}$

On the other hand, it was controlled the presence of the starter culture inoculated throughout the ripening. The analysis of the 16S rRNA region of isolates from the highest dilution confirmed that belong to $P$. acidilactici and $S$. Vitulus species. Therefore, the strains inoculated were around $10^{7} \mathrm{CFU} \mathrm{g}^{-1}$ in the P200S34 and P200S34 + EPg222 batches.

\subsection{Antibacterial activity assay}

Table 1 shows the percentage of inhibition of the extracts obtained from the different batches against E. coli CECT4267. In general, before digestion, the activity values after 60 days were lower than those at 90 days, although there were no significant differences between the days of ripening, except for the batch inoculated with P200S34 culture and protease EPg222. During ripening of sausages, peptides and free amino acids increased due to hydrolysis of the proteins. ${ }^{43-45}$ Thus, at the beginning of the ripening, high molecular weight peptides are generated, but over time, lower molecular weight compounds are formed, ${ }^{46}$ which may be responsible for the antimicrobial activity. Jang et $a .^{13}$ showed strongly antibacterial activity of small peptides (GFHI, DFHING, FHG, and GLSDGEWQ) obtained from beef meat protein hydrolysates. In addition, previous studies in water-soluble extracts obtained from cheese have demonstrated that the antimicrobial activity was significantly affected by the ripening time. ${ }^{20,47}$ Between batches, no significant differences were observed before or after in vitro gastrointestinal digestion, although the digestion caused a significant increase of activity. It is important that the bioactive compounds maintain their bioactivity as they pass through the human digestive system and can perform their roles in the body. ${ }^{30,48}$ Furthermore, this digestion can generate new antimicrobial compounds from other inactive molecules in the extract. ${ }^{29,49}$ It has also been demonstrated in previous studies that the addition of protease EPg222 during the curing process of meat results in the release of peptides and free amino acids that may have functional activities. ${ }^{26}$

For inhibition of the different extracts against $S$. choleraesuis CECT4395, as well as against $E$. coli, the values of inhibition increased from 60 to 90 days of ripening (Table 1). After the simulation in vitro, the extract activity was maintained or even slightly increased in the control and P20034 + EPg222 batches from $7.5 \%$ to $12 \%$ inhibition of growth. Numerous studies have demonstrated the high resistance of Salmonella spp. to different types of antimicrobial compounds due to the different antimicrobial resistance mechanisms. ${ }^{50,51}$ Although inhibition is not high against $S$. choleraesuis, the results are interesting because there are few studies that address the antimicrobial activity against Gramnegative pathogens by meat muscle-derived peptides. ${ }^{24}$

Table 2 shows the percentages of inhibition against S. aureus CECT976, L. monocytogenes CECT911 and B. cereus CECT131. The extracts obtained after 60 days of ripening did not show any inhibition, while at 90 days, the different extracts reached different values of inhibition. No significant differences were observed between the controls and inoculated batches against $S$. aureus CECT976, L. monocytogenes CECT911. The antimicrobial activity of the extract may be due to low molecular weight nitrogen compounds. These compounds are inactive in the native protein, but they can be activated for release during the ripening of sausages. ${ }^{52}$ This could explain why, at 60 days of ripening, there was no antimicrobial activity and, due to the increased amount of low molecular weight compounds throughout ripening, the activity was higher at the end of this process. Proteolysis that takes place

Table 1 Percentage inhibition of the extracts obtained from the different batches against Gram negative bacteria Escherichia coli CECT4267 and Salmonella choleraesuis CECT4395

\begin{tabular}{|c|c|c|c|c|c|c|c|}
\hline & & Sampling time & \multicolumn{2}{|c|}{60 days } & \multicolumn{2}{|c|}{90 days } & $P^{a}$ \\
\hline & & P200S34 & $2.7 \pm$ & & $7.5 \pm$ & & \\
\hline & & EPg222 & $4.3 \pm$ & & $9.3 \pm$ & & \\
\hline & & P200S34 + EPg222 & $0.8 \pm$ & & $11.0 \pm$ & & *** \\
\hline & After digestion & Control & n.d. & & $12.4 \pm$ & & *** \\
\hline & & P200S34 + EPg222 & n.d. & & $12.6 \pm$ & & *** \\
\hline \multirow[t]{5}{*}{ Salmonella choleraesuis CECT4395 } & Before digestion & Control & n.d. & & $5.9 \pm$ & & ** \\
\hline & & P200S34 & n.d. & & $6.2 \pm$ & & ** \\
\hline & & EPg222 & n.d. & & $8.7 \pm$ & & *** \\
\hline & & P200S34 + EPg222 & $8.5 \pm$ & & $7.5 \pm$ & & \\
\hline & After digestion & Control & n.d. & & $12.0 \pm$ & & *** \\
\hline
\end{tabular}

n.d.: Not detected. ${ }^{a} P$-values for 60 and 90 days of ripening: ${ }^{* *} p<0.001 ;{ }^{* *} p<0.01 .{ }^{\text {a,b }}$ For a given determination (column), values with different superscript letters are significantly different $(p<0.001)$. 
Table 2 Percentage inhibition of the extracts obtained from the different batches against Gram positive bacteria Staphylococcus aureus CECT976, Listeria monocytogenes CECT911 and Bacillus cereus CECT131

\begin{tabular}{|c|c|c|c|c|c|c|c|}
\hline & & Sampling time & \multicolumn{2}{|c|}{60 days } & \multicolumn{2}{|c|}{90 days } & $P^{a}$ \\
\hline & & P200S34 & n.d. & & $10.5 \pm$ & & *** \\
\hline & & $\mathrm{EPg} 222$ & n.d. & & $12.5 \pm$ & & *** \\
\hline & & P200S34 + EPg222 & n.d. & & $15.1 \pm$ & & *** \\
\hline & Aft er digestion & Control & n.d. & & $15.7 \pm$ & & *** \\
\hline & & P200S34 + EPg222 & n.d. & & $14.8 \pm$ & & *** \\
\hline \multirow{5}{*}{ Listeria monocytogenes CECT911 } & Before digestion & Control & n.d. & & $7.4 \pm 2$ & & ** \\
\hline & & P200S34 & n.d. & & $6.5 \pm 1$ & & ** \\
\hline & & EPg222 & n.d. & & $7.3 \pm 2$ & & ** \\
\hline & & P200S34 + EPg222 & n.d. & & $3.8 \pm 0$ & & \\
\hline & After digestion & Control & n.d. & & $0.9 \pm 1$ & & \\
\hline & & EPg222 & n.d. & & $23.2 \pm$ & & *** \\
\hline & & P200S34 + EPg222 & n.d. & & $24.3 \pm$ & & *** \\
\hline & After digestion & Control & n.d. & & $19.3 \pm$ & & *** \\
\hline & & P200S34 & n.d. & & $19.0 \pm$ & & *** \\
\hline & & EPg222 & n.d. & & $21.1 \pm$ & & *** \\
\hline & & P200S34 + EPg222 & n.d. & & $22.8 \pm$ & & *** \\
\hline
\end{tabular}

n.d.: Not detected. ${ }^{a} P$-values for 60 and 90 days of ripening: ${ }^{* *} p<0.001 ;{ }^{* *} p<0.01 .{ }^{\mathrm{a}, \mathrm{b}}$ For a given determination (column), values with different superscript letters are significantly different $(p<0.001)$.

during ripening of meat products is influenced by the starter cultures used ${ }^{53}$ with microbial proteolysis being most important during the last stages of ripening. ${ }^{53,54}$ Differences in the spectrum of action, inhibitory concentration, and even influence in the anti-listerial activity by the time of ripening have been observed by Rizzello et al. ${ }^{20}$ and Lignitto et al. ${ }^{47}$ in dairy products. Moreover, different authors have reported inhibition of $L$. monocytogenes growth by LAB during the ripening of drycured sausages, and this antimicrobial effect was probably due to other factors, such as organic acid production or bacteriocins by LAB. ${ }^{55,56}$

Respect to activity against B. cereus CECT131 after 90 days of sausage ripening the extracts clearly inhibited growth, reaching values of around $25 \%$ inhibition, which is the highest percentage of inhibition obtained with the different microorganisms tested. The control batch showed lower activity than the other extracts. After simulated gastrointestinal digestion, all extract values were maintained except for the P200S34 batch, which suffered a significant decline in activity. B. cereus has been isolated from fresh meat and meat products. ${ }^{57-59}$ This microorganism grows at temperatures between $5{ }^{\circ} \mathrm{C}$ and $55{ }^{\circ} \mathrm{C}$, and $\mathrm{pH} 4.5$ to 9.3 , and supports up to $7.5 \%$ salt, which enables it to grow easily in dry-cured sausages. The toxin production is shown to be greater at $12-15{ }^{\circ} \mathrm{C}$ than at $30{ }^{\circ} \mathrm{C},{ }^{60}$ which makes $B$. cereus a microbiological risk to consider in meat products. ${ }^{1}$ This antimicrobial activity against B. cereus is interesting because few antimicrobial peptides, such as bacteriocins produced by $\mathrm{LAB}^{61}$ or meat proteinderived peptides, ${ }^{13}$ are effective to this species.

The high proteolytic activity of EPg222 has been previously demonstrated during ripening of pork sausages, either alone or with high proteolytic starter cultures. ${ }^{26,28,62}$ Therefore, it is reasonable to expect higher antimicrobial activity in nitrogen extracts from batches containing EPg222 or P200S34, both together or separately, due to the increased diversity of nitrogen compounds as a consequence of the stronger proteolysis by the protease or microbial enzymes. In fact, the highest antimicrobial activity was generally obtained from the extracts of EPg222 and P200S34 + EPg222 batches. Furthermore, longer maturation involves greater proteolysis and may also have a positive impact on the generation of different nitrogen compounds with antimicrobial activity, which was clearly demonstrated in our results. Therefore, the results of this study show that the control of the ripening process of dry-fermented sausages with proteolytic starter cultures, alone or in combination with protease EPg222, can lead to the production of nitrogen compounds with moderate antimicrobial activity, thus potentially contributing to controlling the presence of foodborne pathogens and ensuring the hygienic quality of this meat product.

\subsection{Determination of antiproliferative activity on HT-29 cell line}

Fig. 1 shows the antiproliferative activity of the nitrogen extracts prior to and after simulated gastrointestinal digestion 


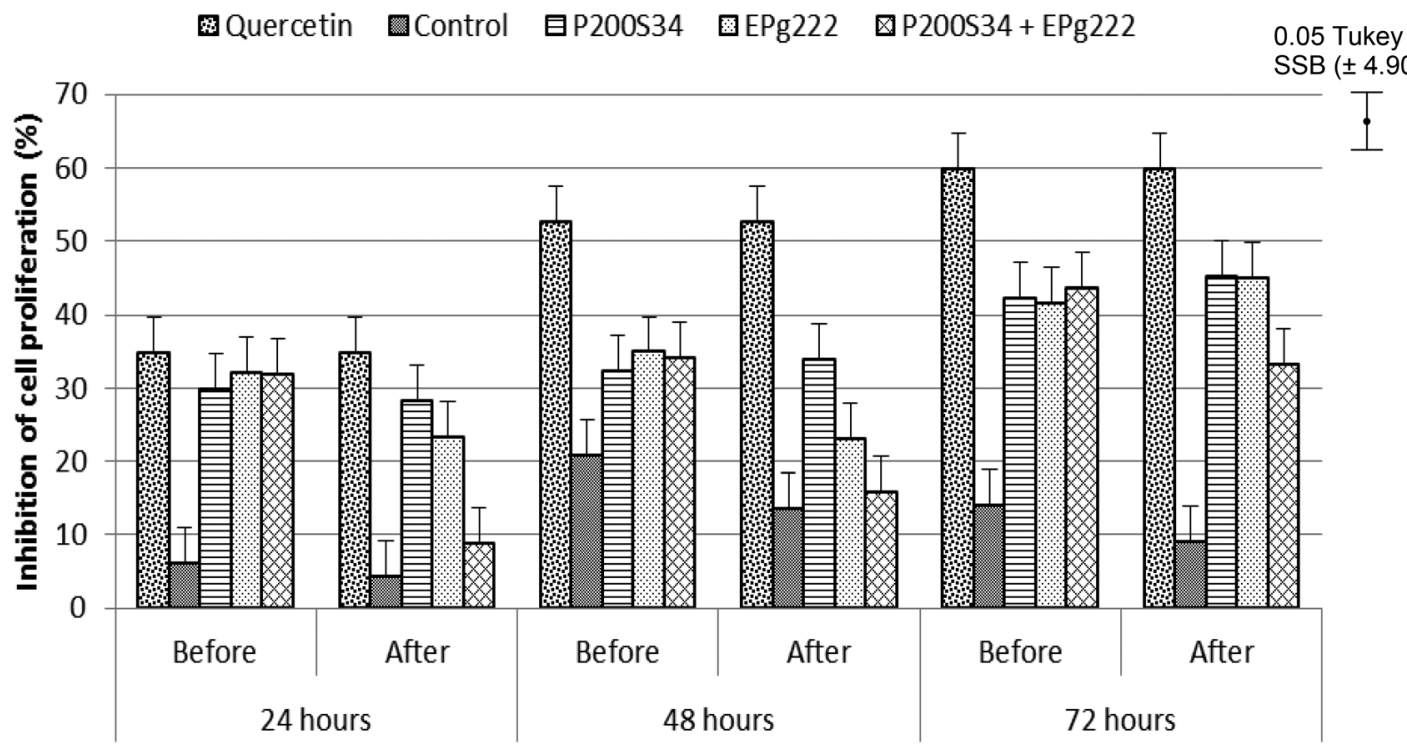

Fig. 1 Effect on HT-29 cell line proliferation of nitrogen compound extracts, before and after gastrointestinal digestion, obtained from dry-fermented sausage manufactured with autochthonous starter cultures and protease EPg222 after 90 days of ripening. Results are expressed as percentage of inhibition, and the statistical significances difference bar (SSB; $p<0.05$ ) using the Tukey HSD test between batches is shown.

against the HT-29 human colon cancer cell line. The antiproliferative activity of the nitrogen extracts from dry-cured sausage elaborated with the addition of the starter culture P200S34 and protease EPg222, either together or separately, were compared with control extracts from sausages without inoculation and with the flavonoid quercetin, which has previously been described as a compound with anticancer activity. ${ }^{63}$ No significant differences in activity were obtained in the batches at 60 days (data not shown) and 90 days. The time of ripening did not lead to an increase in the antiproliferative activity. However, a significantly higher inhibition of cell proliferation was observed with nitrogen extracts from inoculated batches (P200S34, EPg222 and P200S34 + EPg222) throughout the experiment than in the control batch $(p<0.05)$. Furthermore, the inhibition exerted by the inoculated batches was similar to the values obtained with the positive control (quercetin) at $24 \mathrm{~h}$ of the experiment. However, at $72 \mathrm{~h}$, the values were significantly lower, although they maintained moderate activity, i.e. around $45 \%$ inhibition. The addition of highly proteolytic enzymes and a starter culture can contribute to this process and it is logical to expect an effect in the nitrogen compound profile and in their biological properties. Several studies have shown that the use of a commercial protease is an efficient way to produce bioactive compounds from food proteins. ${ }^{13,64}$

We also investigated the effect of simulated gastrointestinal digestion on the nitrogen compound extracts. The antiproliferative activity was barely affected after the treatment on extracts from the control and PS200S34 batches. In fact, in the PS200S34 batch, the values of activity were practically identical to those without digestion, although at $72 \mathrm{~h}$, they were slightly higher. However, in the batches inoculated with the enzyme (EPg222 and P200S34 + EPg222), there was a significant decrease in the activity, although this impact was lower in the batch inoculated with the enzyme alone, where at $72 \mathrm{~h}$, the activity was higher after gastrointestinal digestion. Although these results show a negative effect of gastrointestinal digestion on the nitrogen compounds related to the antiproliferative activity at the beginning of assay, at $72 \mathrm{~h}$, only a slight decrease was observed in the P200S34 + EPg222 batch.

To date, there are no studies about the antiproliferative capacity of nitrogen extracts obtained from fermented meat products. Previous works have studied mainly the antioxidant and antihypertensive properties of meat-derived peptides. ${ }^{25}$ Jang et $a l^{13}$ investigated the antiproliferative capacity of peptides obtained from bovine meat protein after treatment with commercial proteolytic enzymes on breast adenocarcinoma (MCF-7), stomach adenocarcinoma (AGS) and lung carcinoma (A549) cell lines. The peptide GLSDGEWQ showed a remarkable inhibition of AGS proliferation by $80 \%$, at a dose of $0.4 \mathrm{mg} \mathrm{mL} \mathrm{m}^{-1}$, while peptide GFHI slightly decreases the proliferation of MCF-7 cells. However, a significant reduction of cell proliferation in colon and breast cancer cell lines has been widely described in hydrolysed protein of other food matrices, such as fish ${ }^{65,66}$ and milk. ${ }^{67-70}$

\subsection{HLPC-ESI-MS analysis of the extracts}

The analysis of the low molecular weight nitrogen compounds of different batches at the final ripening stage allowed detection of a total of 22 major compounds, 13 of which were potentially identified (Table 3). The extracts were mainly constituted by several endogenous compounds and their degradation products (6), but also small peptides (9), free amino acids (6), and biogenic amines (1) from meat protein degradation. Most of the identified nitrogen compounds have been reported as majority components of the NPN fraction in meat products, including fermented sausages. ${ }^{71}$ 
Table 3 Nitrogen compounds detected by HPLC-ESI-MS in extracts of 'salchichón' batches at the end of the ripening process

\begin{tabular}{|c|c|c|c|c|c|c|c|c|c|c|c|c|c|}
\hline \multirow[b]{2}{*}{ Rt } & \multirow[b]{2}{*}{$\mathrm{Cd}^{a}$} & \multirow[b]{2}{*}{ Compound } & \multirow[b]{2}{*}{$\mathrm{ID}^{b}$} & \multirow[b]{2}{*}{$m / z^{c}$} & \multirow[b]{2}{*}{ Mass fragments } & \multicolumn{4}{|c|}{ Before $\mathrm{SDGI}^{d}$} & \multicolumn{4}{|c|}{ After SDGI $^{d}$} \\
\hline & & & & & & Min & Max & Mean & SD & Min & $\operatorname{Max}$ & Mean & SD \\
\hline \multicolumn{6}{|c|}{ Natural compounds } & & & 19.33 & & & & 27.21 & \\
\hline 1.9 & $\mathrm{~N} 1$ & Taurine & a & 126.1 & $109.1 ; 126.1$ & 0.84 & 1.35 & 1.09 & 0.19 & 0.52 & 1.41 & 0.83 & 0.29 \\
\hline 2.37 & $\mathrm{~N} 2$ & Carnosine & $\mathrm{b}$ & 227.1 & $227.1 ; 210.1$ & 7.79 & 11.86 & 10.73 & 1.20 & 5.29 & 9.79 & 7.43 & 1.27 \\
\hline 2.49 & N3 & Anserine & $\mathrm{b}$ & 241.1 & $241.1 ; 170.1$ & 0.74 & 1.39 & 0.98 & 0.17 & 0.00 & 0.18 & 0.09 & 0.06 \\
\hline 2.54 & N4 & Carnitine & a & 162.1 & 162.1 & 4.28 & 8.26 & 6.53 & 1.41 & 2.66 & 4.98 & 3.55 & 0.65 \\
\hline 2.8 & N5 & Creatine & b & 132.1 & $132.1 ; 115.1$ & & & n.d. & & 12.44 & 23.52 & 15.31 & 3.13 \\
\hline 2.81 & N6 & Creatinine & $\mathrm{b}$ & 114.1 & 114.1 & & & n.d. & & & & n.d. & \\
\hline \multicolumn{8}{|c|}{ Amino acids and amines } & 46.20 & & & & 55.27 & \\
\hline 2.17 & A1 & Lysine & a & 147.1 & $130.1 ; 147.1$ & 1.79 & 7.28 & 5.14 & 1.50 & 6.73 & 12.18 & 9.44 & 1.92 \\
\hline 2.56 & A2 & Proline & a & 116.1 & 116.1 & 2.36 & 9.65 & 5.58 & 2.11 & 0.42 & 11.55 & 3.23 & 3.64 \\
\hline 6.29 & $\mathrm{~A} 3$ & Methionine & a & 150.1 & $133 ; 150.1$ & 0.72 & 2.45 & 1.64 & 0.56 & 0.33 & 6.36 & 2.26 & 1.59 \\
\hline 14.1 & $\mathrm{~A} 4$ & Isoleucine & a & 132.1 & 132.1 & 1.17 & 20.25 & 10.87 & 6.21 & 0.00 & 31.40 & 10.94 & 9.35 \\
\hline 15.24 & A5 & Leucine & a & 132.1 & 132.1 & 1.19 & 23.70 & 18.35 & 6.56 & 0.00 & 34.75 & 18.47 & 9.63 \\
\hline 16.31 & A6 & Tyramine & a & 121.1 & $121.1 ; 138.1$ & 0.00 & 0.06 & 0.01 & 0.02 & 2.68 & 4.81 & 3.50 & 0.58 \\
\hline 31.09 & A7 & Phenylalanine & a & 166.1 & $120.1 ; 166.1$ & 3.15 & 7.91 & 4.61 & 1.49 & 0.86 & 9.19 & 7.43 & 2.18 \\
\hline \multicolumn{6}{|c|}{$\begin{array}{l}\text { Presumed peptides and other } \\
\text { compounds }\end{array}$} & & & 20.8 & & & & 17.51 & \\
\hline 2.1 & P1 & Compound 1 & c & 190.9 & $190.9 ; 380.9 ; 478.9 ; 614.9 ; 750.9$ & 0.76 & 8.39 & 3.34 & 2.46 & 0.78 & 2.95 & 1.80 & 0.69 \\
\hline 2.15 & P2 & Compound 2 & c & 118.1 & $118.1 ; 203.1$ & 7.10 & 13.63 & 9.89 & 2.25 & 0.94 & 11.70 & 9.74 & 2.90 \\
\hline 2.23 & P3 & Compound 3 & c & 365.1 & 365.1 & 0.68 & 3.30 & 1.89 & 0.61 & 0.70 & 4.55 & 2.15 & 1.07 \\
\hline 3.16 & P4 & Compound 4 & c & 146.1 & 146.1 & & & n.d. & & & & n.d & \\
\hline 3.36 & P5 & Compound 5 & c & 277.1 & $227.1 ; 407.1 ; 504.1$ & & & n.d. & & & & n.d & \\
\hline 4.7 & P6 & Compound 6 & $\mathrm{c}$ & 124.1 & 124.1 & 0.00 & 1.91 & 0.16 & 0.55 & 0.00 & 2.33 & 1.55 & 0.57 \\
\hline 5.63 & P7 & Compound 7 & $\mathrm{c}$ & 159.1 & $159.1 ; 295.1$ & & & n.d. & & & & n.d & \\
\hline 5.93 & P8 & Compound 8 & c & 137.1 & 137.1 & 2.66 & 11.12 & 5.15 & 2.44 & 0.00 & 2.33 & 1.55 & 0.57 \\
\hline 7.28 & P9 & Compound 9 & c & 205.1 & 204.1 & 0.26 & 0.56 & 0.37 & 0.10 & 0.00 & 1.04 & 0.72 & 0.25 \\
\hline
\end{tabular}

${ }^{a}$ Code used in PCA analysis. ${ }^{b}$ Identification levels: a: standard; b: data base mass bank (http://www.massbank.jp); c: unidentified compound. ${ }^{c}$ The most abundant fragment ions. ${ }^{d}$ Values expressed in percentage of the main fragment ions of the nitrogen compounds detected.

A group of nitrogen compounds that included amino acids and amines were the most abundant compounds in the extract profiles. The free amino acids Lys, Leu, Ile, Pro, Met and Phe, which were detected in the studied extracts, have been described as being among the most abundant compounds derived from proteolytic activity during the process of sausage fermentation. ${ }^{26,72}$ The biogenic amine tyramine was also detected, which is produced mainly by microbial decarboxylation of free amino acids that are formed during the maturation process. ${ }^{73}$

Another group of nitrogen compounds included natural nitrogen compounds. This group of compounds included carnosine $(7.79-11.86 \%$ of total area) as the major component. This compound, together with carnitine, was most abundant in batches before simulated gastrointestinal digestion. In contrast, creatine (12.44-23.52\% of the total area) was most abundant in samples after gastrointestinal digestion.

Finally, the group of presumed peptides (a total of nine compounds) at the final stage of ripening represented $20.8 \%$ and $17.51 \%$ of the total area for batches before and after SDGI, respectively (Table 3). These percentages suggest a noticeable influence of these compounds on functional activities of the extracts. The compounds with $\mathrm{m} / \mathrm{z} 146,277$ and 159 were not found in significant amounts.

In order to determine the influence of the extract components on the activities studied, a PCA was performed with the extract profiles of the samples obtained at the final stage of the ripening process before simulation of gastrointestinal digestion in vitro and their antibacterial and antiproliferative activities (Fig. 2 and 3). Before simulated gastrointestinal digestion, the natural nitrogen compounds and most of the presumed peptides were mainly explained by the first axis (PC1) of the PCA. These compounds were mainly linked to samples of the highly proteolytic P200S34 + EPg222 batch, suggesting a higher proportion of NPN derived from proteolysis products in the extracts of inoculated batches. In fact, the second axis (PC2) of the PCA was defined by antibacterial activities. Methionine and lysine showed a significant correlation with the antiproliferative activity. Lysine was related to the antiproliferative activity and has been widely used in combination with arginine and ascorbic acid, among others, to inhibit the growth of cancer cell lines. ${ }^{74-76}$

Regarding the samples after simulated gastrointestinal digestion, again the natural nitrogen compounds and most of the presumed peptides were related with the first axis (PC1) of the PCA, while activities were again mainly explained by the second axis (PC2; Fig. 3). In this case, the relationship between the antiproliferative activity and methionine and lysine was also observed. The inoculated batches were associated with natural nitrogen compounds, amino acids and presumed peptides, probably as a consequence of the higher proteolytic activity of autochthonous 


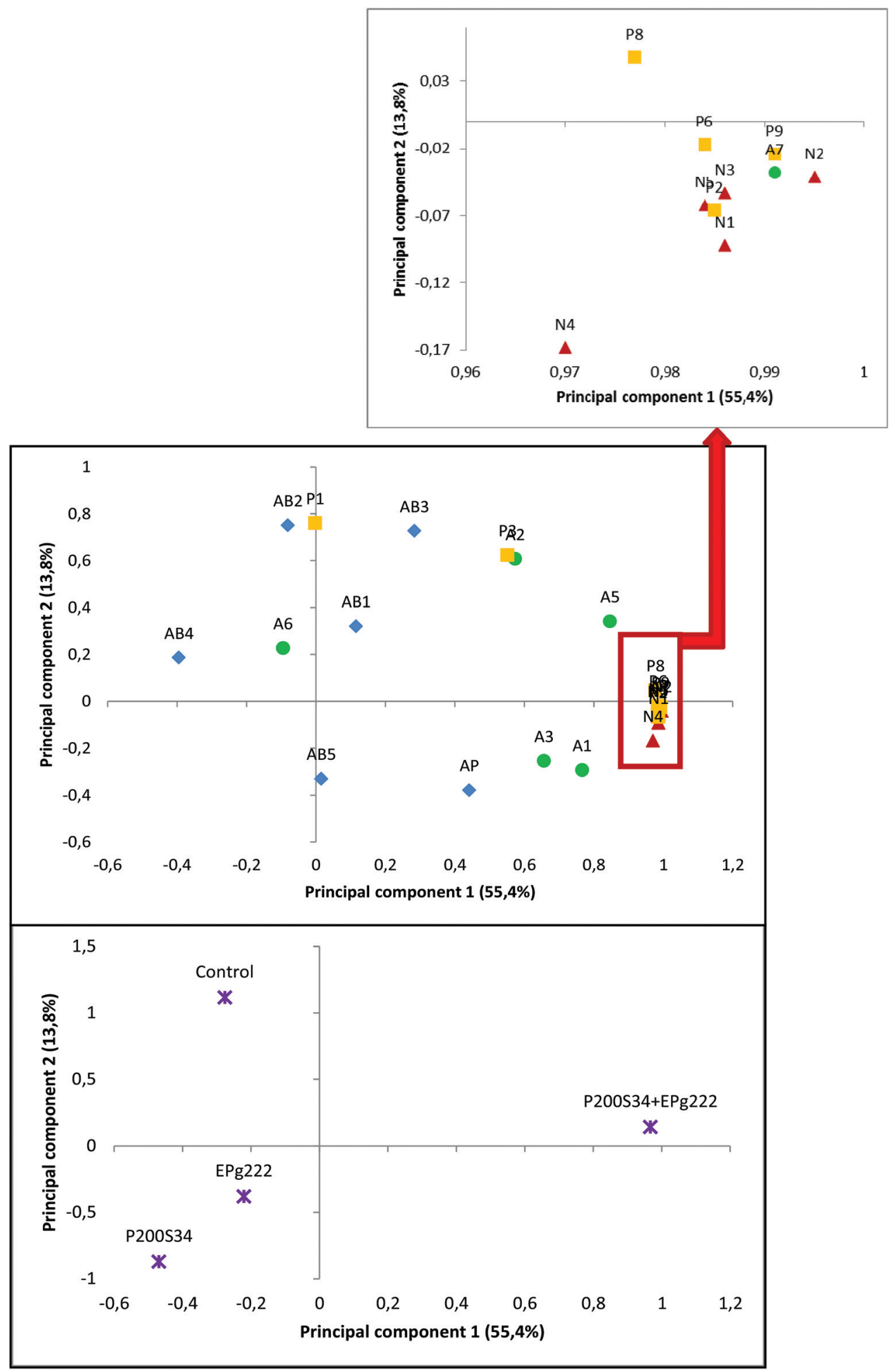

Fig. 2 PC1 and PC2 (55.4\% and 13.8\% of explained variance, respectively) of the PCA for the 'Salchichón' samples during processing. Score plot showing the detected nitrogen compounds in the peptidic extracts and the antibacterial and antiproliferative activities, before gastrointestinal digestion. Codes: N1-N6; A1-A7; P1-P9, nitrogen compounds in Table 3. AP: antiproliferative activity; AB1: antibacterial activity against Escherichia coli; AB2: antibacterial activity against Salmonella cholerasuis; AB3: antibacterial activity against Staphylococcus aureus; AB4: antibacterial activity against Listeria monocytogenes; AB5: antibacterial activity against Bacillus cereus. 


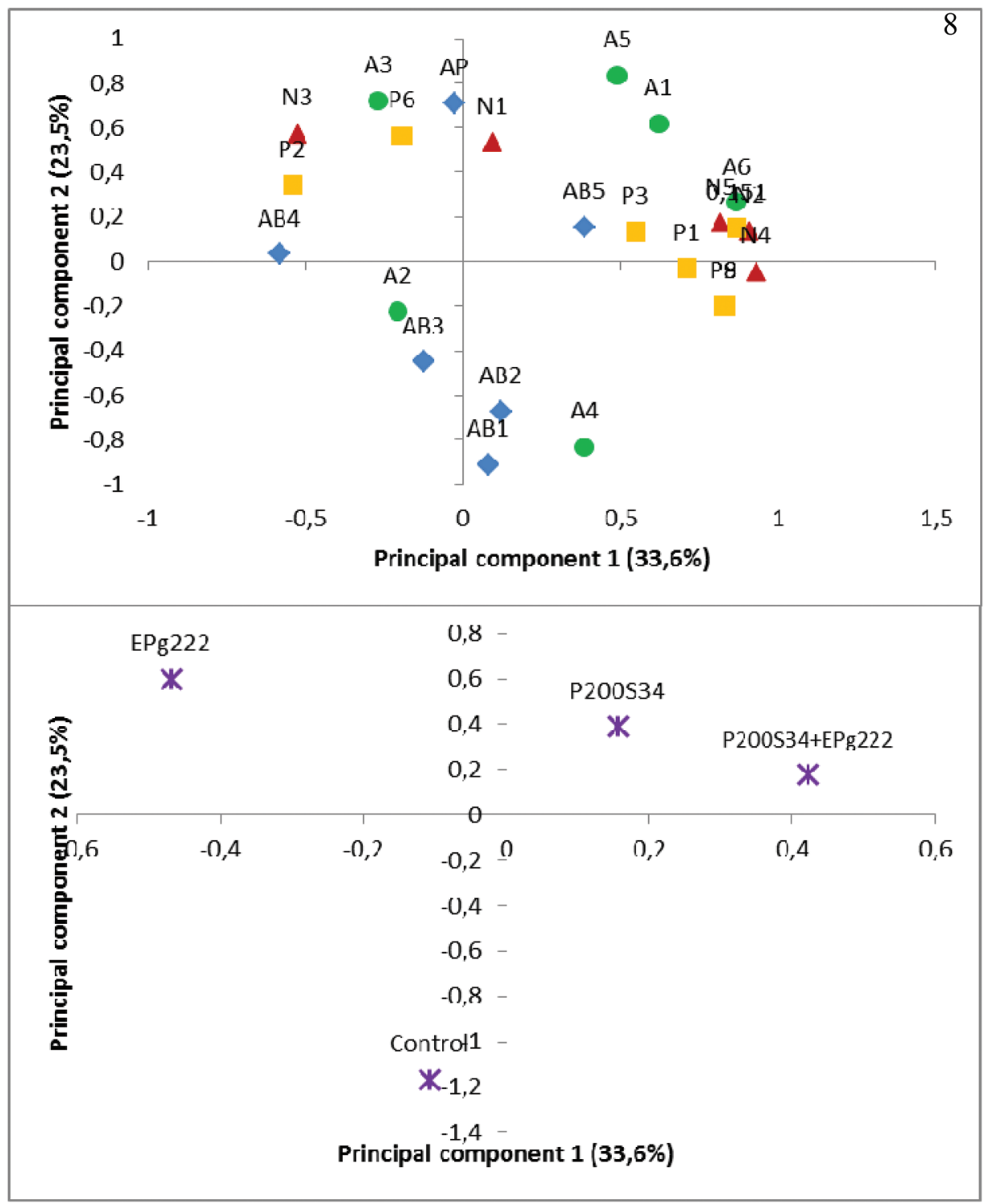

Fig. 3 PC1 and PC2 (33.6\% and 23.5\% of explained variance, respectively) of the PCA for the 'Salchichón' samples during processing. Score plot showing the detected nitrogen compounds in the peptidic extracts and the antibacterial and antiproliferative activities, after gastrointestinal digestion. Codes: N1-N6; A1-A7; P1-P9, nitrogen compounds in Table 3. AP: antiproliferative activity; AB1: antibacterial activity against Escherichia coli; AB2: antibacterial activity against Salmonella cholerasuis; AB3: antibacterial activity against Staphylococcus aureus; AB4: antibacterial activity against Listeria monocytogenes; AB5: antibacterial activity against Bacillus cereus.

microorganisms in this meat product. However, the control samples were only associated with antibacterial activity.

In both cases, before and after simulated gastrointestinal digestion, the antibacterial activity could be attributed to minor nitrogen compounds, since this activity was not associated with any of the major compounds found in the studied extracts.

\section{Conclusions}

The microbial population in fermented sausages significantly influences the profile of the low molecular weight nitrogen compounds and the functional activities. We can conclude that starter culture P200S34 and protease EPg222 generate extracts that cause inhibition of the growth of pathogens, making this a promising tool for biocontrol in the meat industry. On the other hand, the inoculation of well-adapted starter cultures with high proteolytic activity increased the antiproliferative activity of these extracts, mainly due to a higher amount of free amino acids, such as Lys and Pro, but also small peptides.

\section{Acknowledgements}

This work formed part of the Projects PDT05A037 and PDT08A062 funded by the Consejería de Educación y Tecnolo- 
gía (Junta de Extremadura co-funded with FEDER funding). Margarita Fernández received a grant from the Valhondo Calaff Foundation. The authors are grateful to Mariano Cabrero and Juan Hernández for their technical assistance.

\section{References}

1 E. Borch and P. Arinder, Meat Sci., 2002, 62, 381-390.

2 V. Ferreira, J. Barbosa, S. Verdeiro, A. Mota, F. Silva, M. A. Monteiro, T. Hogg, P. Gibbs and P. Teixeira, Meat Sci., 2006, 73, 570-575.

3 V. Ferreira, J. Barbosa, J. Silva, M. T. Felicio, C. Mena, T. Hogg, P. Gibbs and P. Teixeira, Food Control, 2007, 18, 436-440.

4 R. Casquete, M. J. Benito, A. Martín, S. Ruiz-Moyano, E. Aranda and M. G. Córdoba, Food Control, 2012, 24, 191198.

5 J. E. Moore, Meat Sci., 2004, 67, 565-568.

6 C. Xavier, U. Gonzales-Barron, V. Paula, L. Estevinho and V. Cadavez, Food Res. Int., 2014, 55, 311-323.

7 F. Leroy and L. De Vuyst, Trends Food Sci. Technol., 2004, 15, 67-78.

8 M. S. Ammor and B. Mayo, Meat Sci., 2007, 76, 138-146.

9 M. Hugas, Meat Sci., 1998, 49, S139-S150.

10 U. Schillinger, R. Geisen and W. H. Holzapfel, Trends Food Sci. Technol., 1996, 7, 158-164.

11 F. Leroy, J. Verluyten and L. De Vuyst, Int. J. Food Microbiol., 2006, 106, 270-285.

12 Y. Mine, F. P. Ma and S. Lauriau, J. Agric. Food Chem., 2004, 52, 1088-1094.

13 A. Jang, C. Jo, K. S. Kang and M. Lee, Food Chem., 2008, 107, 327-336.

14 D. Gong, J. Kalina, M. M. Bain, P. W. Wilson and I. C. Dunn, British Poultry Abstract, 2009, 5, 8-9.

15 R. A. Silva, M. S. F. Lima, J. B. M. Viana, V. S. Bezerra, M. C. B. Pimentel, A. L. F. Porto, M. T. H. Cavalcanti and J. L. Lima Filho, Food Chem., 2012, 135, 1533-1538.

16 A. Sibel Akalın, Trends Food Sci. Technol., 2014, 36, 79-95.

17 G. Mauriello, A. Casaburi, G. Blaiotta and F. Villani, Meat Sci., 2004, 67, 149-158.

18 M. Flores and F. Toldrá, Trends Food Sci. Technol., 2011, 22, 81-90.

19 V. Gagnaire, D. Mollé, M. Herrouin and J. Léonil, J. Agric. Food Chem., 2011, 49, 4402-4413.

20 C. G. Rizzello, I. Losito, M. Gobbetti, T. Carbonara, M. D. De Bari and P. G. Zambonin, J. Dairy Sci., 2005, 88, 2348-2360.

21 J. S. Lee, S. J. Rho, Y. W. Kim, K. W. Lee and H. G. Lee, Food Sci. Biotechnol., 2013, 22, 973-978.

22 S. H. Kaufmann and W. C. Earnshaw, Exp. Cell Res., 2000, 256, 42-49.

23 D. S. Lind, S. N. Hochwald, J. Malaty, S. Rekkas, P. Hebig, G. Mishra, L. L. Moldawer, E. M. Copeland and S. MacKay, Surgery, 2001, 130, 363-369.

24 T. Lafarga and M. Hayes, Meat Sci., 2014, 98, 227-239.
25 J. Stadnik and P. Kęska, Acta Sci. Pol., Technol. Aliment., 2015, 14, 181-190.

26 M. J. Benito, M. Rodríguez, M. G. Córdoba, M. J. Andrade and J. J. Córdoba, J. Sci. Food Agric., 2005, 85, 273-280.

27 M. J. Benito, I. F. Connerton and J. J. Córdoba, Appl. Microbiol. Biotechnol., 2006, 73, 356-365.

28 R. Casquete, M. J. Benito, A. Martín, S. Ruiz-Moyano, J. J. Córdoba and M. G. Córdoba, Food Microbiol., 2011, 28, 1432-1440.

29 A. Martín, B. Colín, E. Aranda, M. J. Benito and M. G. Córdoba, Meat Sci., 2007, 75, 696-708.

30 M. J. Benito, M. Serradilla, A. Martín, E. Aranda, A. Hernández and M. G. Córdoba, Food Microbiol., 2008, 25, 676-682.

31 K. J. Rutherfurd-Markwick, Br. J. Nutr., 2012, 108, 149-157.

32 H. Korhonen and A. Pihlanto, Int. Dairy J., 2006, 16, 945960.

33 M. J. Benito, A. Martín, E. Aranda, F. Pérez-Nevado, S. RuizMoyano and M. G. Córdoba, J. Food Sci., 2007, 72, M193M201.

34 ISO, Meat and meat product-determination of moisture content method 1442, Geneva, 1973.

35 M. J. Benito, M. J. Serradilla, S. Ruiz-Moyano, A. Martín, F. Pérez-Nevado and M. G. Córdoba, Meat Sci., 2008, 80, 656-661.

36 A. De Ketelaere, D. Demeyer, P. Vandekerckhove and I. Vervaeke, J. Food Sci., 1974, 39, 297-300.

37 C. Bauchart, D. Rémond, C. Chambon, P. Patureau Mirand, I. Savary-Auzeloux, C. Reynès and M. Morzel, Meat Sci., 2006, 74, 658-666.

38 C. D. Cinq-Mars, C. Hu, D. D. Kitts and E. C. Y. Li-Chan, J. Agric. Food Chem., 2008, 56, 410-419.

39 L. You, M. Zhao, J. M. Regestein and J. Ren, Food Chem., 2010, 120, 810-816.

40 S. Ruiz-Moyano, A. Martín, M. J. Benito, R. Casquete, M. J. Serradilla and M. G. Córdoba, Meat Sci., 2009, 83, 460-467.

41 H. Olsen, S. Grimmer, K. Aaby, S. Saha and G. I. A. Borge, J. Agric. Food Chem., 2012, 60, 7375-7383.

42 J. A. Gómez-Ruiz, I. López-Expósito, A. Pihlanto, M. Ramos and I. Recio, Eur. Food Res. Technol., 2008, 227, 1061-1067.

43 T. W. DeMasi, F. B. Wardlaw, R. L. Dick and J. C. Acton, Meat Sci., 1990, 27, 1-12.

44 O. Díaz, M. Fernández, G. D. García de Fernando, L. De la Hoz and J. A. Ordóñez, J. Sci. Food Agric., 1996, 71, 13-21.

45 T. Bolumar, P. Nieto and J. Flores, Food Sci. Technol. Int., 2001, 7, 269-276.

46 A. P. Henriksen and L. H. Stahnke, J. Agric. Food Chem., 1997, 45, 2679-2684.

47 L. Lignitto, S. Segato, S. Balzan, V. Cavatorta, N. Oulahal, S. Sforza, P. Degraeve, G. Galaverna and E. Novelli, Dairy Sci. Technol., 2012, 92, 297-308.

48 O. Martínez Augustín and E. Martínez de Victoria, Nutr. Hosp., 2006, 21, 1-14.

49 V. Vermeirssen, J. Van Camp and W. Verstraete, Br. J. Nutr., 2004, 92, 357-366. 
50 S. A. McEwen and J. Fedorka-Cray, Clin. Infect. Dis. J., 2002, 34, S93-S106.

51 S. L. Foley and A. M. Lynne, J. Anim. Sci., 2007, 86, E173-E187.

52 J. Vioque and F. Millán, AgroCSIC, 2005, 26, 103-107.

53 M. C. Hughes, J. P. Kerry, E. K. Arendt, P. M. Kenneally, P. L. H. McSweeney and E. E. O’Neill, Meat Sci., 2002, 62, 205-216.

54 G. Lizaso, J. Chasco and J. Beriain, Food Microbiol., 1999, 6, 219-228.

55 R. Callewaert, M. Hugas and L. De Vuys, Int. J. Food Microbiol., 2000, 57, 33-42.

56 R. E. de Macedo, L. Miyague, L. B. Costa and L. Bittencourt, Afr. J. Microbiol. Res., 2013, 7, 710-718.

57 P. Van Netten, A. Van de Moosdijk, P. Van Hoesel, D. A. A. Mossel and I. Perales, J. Appl. Bacteriol., 1990, 69, 73-79.

58 M. C. Giffel, R. R. Beumer, S. Leijendekkers and F. M. Rombouts, Food Microbiol., 1996, 13, 53-58.

59 H. Konuma, K. Shinagawa, M. Tokumaru, Y. Onoue, S. Konno, N. Fujino, T. Shigehisa, H. Kurata, Y. Kuwabara and C. A. M. Lopes, J. Food Protect, 1988, 51, 324-326.

60 W. J. J. Finlay, N. A. Logan and A. D. Sutherland, Lett. Appl. Microbiol., 2000, 31, 385-389.

61 F. K. Lücke, Meat Sci., 2000, 56, 105-115.

62 M. J. Benito, M. Rodríguez, A. Martín, E. Aranda and J. J. Córdoba, Meat Sci., 2004, 67, 497-505.

63 A. J. Vargas and R. Burd, Nutr. Rev., 2010, 68, 418-428.

64 K. Katayama, H. E. Anggraeni, T. Mori, A. M. Ahhmed, S. Kawahara, M. Sugiyama, T. Akayama, M. Maruyama and M. Muguruma, J. Agric. Food Chem., 2008, 56, 355-360.
65 L. Picot, S. Bordenave, S. Didelot, I. Fruitier-Arnaudin, F. Sannier, G. Thorkelsson, J. P. Bergé, F. Guérard, A. Chabeaud and J. M. Piot, Process Biochem., 2006, 41, 1217-1222.

66 K. C. Hsu, E. C. Li-Chan and C. L. Jao, Food Chem., 2011, 126, 617-622.

67 L. S. Ganjam, W. H. Thornton, R. T. Marshall and R. S. MacDonald, J. Dairy Sci., 1997, 80, 2325-2329.

68 S. Yasuda, N. Ohkura, K. Suzuki, M. Yamasaki, K. Nishiyama, H. Kobayashi, Y. Hoshi, Y. Kadooka and K. Igoshi, J. Dairy Sci., 2010, 93, 1393-1400.

69 C. De Simone, G. Picariello, G. Mamone, P. Stiuso, A. Dicitore, D. Vanacore, L. Chianese, F. Addeo and P. Ferranti, J. Pept. Sci., 2009, 15, 251-258.

70 C. De Simone, P. Ferranti, G. Picariello, I. Scognamiglio, A. Dicitore, F. Addeo, L. Chianese and P. Stiuso, Mol. Nutr. Food Res., 2011, 55, 229-238.

71 J. M. Broncano, J. Otte, M. J. Petrón, V. Parra and M. L. Timón, Meat Sci., 2012, 90, 494-501.

72 A. Leggio, E. L. Belsito, R. D. Marco, M. L. Di Gioia, A. Liguori, C. Siciliano and M. Spinella, J. Food Sci., 2012, 77, S170-S175.

73 G. Suzzi and F. Gardini, J. Food Microbiol., 2003, 88, 4154.

74 S. P. Netke, M. W. Roomi, V. Ivanov, A. Niedzwiecki and M. Rath, Res. Commun. Pharmacol. Toxicol., 2003, 8, IV-37.

75 M. W. Roomi, V. Ivanov, T. Kalinovsky, A. Niedzwiecki and M. Rath, Med. Oncol., 2005, 22, 129-138.

76 M. W. Roomi, V. Ivanov, S. Netke, T. Kalinovsky, A. Niedzwecki and M. Rath, In Vivo, 2006, 20, 25-32. 